\title{
Variation in cheliped form in two species of squat lobsters (Decapoda: Anomura) from Chile
}

\author{
Aníbal H. Lezcano ${ }^{1,2}$, Miguel A. Penna ${ }^{4}$,Federico Márquez ${ }^{1,3}$, Martin Thiel $^{4}$
}

\author{
${ }^{1}$ Centro Nacional Patagónico, Consejo Nacional de Investigaciones Científicas y Técnicas \\ (Boulevard Brown 2915, Puerto Madryn (U9120ACD), Chubut, Argentina) \\ ${ }^{2}$ Universidad Nacional de Comahue \\ (Quintral 1250 (8400), Bariloche, Río Negro, Argentina) \\ ${ }^{3}$ Universidad Nacional de la Patagonia San Juan Bosco \\ (Boulevard Brown 3100, Puerto Madryn (U9120ACD), Chubut, Argentina) \\ ${ }^{4}$ Facultad de Ciencias del Mar, Universidad Católica del Norte \\ (Larrondo 1281, Coquimbo, Chile)
}

*Corresponding author: lezcano@cenpat-conicet.gob.ar

\section{Abstract}

The current study describes the variation in cheliped form of two species of squat lobsters that inhabit the continental margin off Chile: Cervimunida johni and Pleuroncodes monodon. We compared their cheliped form in the context of the reproductive strategy. The general tendency of form variation of both species is similar: chelipeds change, on average, from longer and narrower pollex with short manus to a relatively shorter and wider pollex with longer manus from small to large individuals, respectively. The degree of cheliped arching was greater in males than in females of similar carapace length, and only $C$. johni males showed fully arched morphology. The allometric trajectories (cheliped shape vs. carapace length) were largely aligned with vectors of mean shape difference in both species. Cheliped form variation of $C$. johni (extended mate-guarding) resembles the cheliped morphology reported for the related species Munida rugosa more than P. monodon (short mate-guarding). Our results are consistent with previous finding and suggest that the cheliped form variation (from straight and slender to a fully arched morphology) is, or has been, subject to sexual selection through male-male competition for mates.

Descriptors: Cervimunida johni, Pleuroncodes monodon, Geometric morphometric, Reproductive strategy.

\section{Resumo}

O presente estudo contém uma descrição da variação da forma dos quelípodos de duas espécies de lagostas que habitam a margem continental do Chile: Cervimunida johni e Pleuroncodes monodon. Foi comparada a forma dos quelípodos das espécies em relação à estratégia reprodutiva das espécies. Das espécies estudadas, C. johni apresenta um quelípodo arqueado, uma relação mais estreita entre a forma da quelípodo e comprimento da carapaça e um maior dimorfismo sexual. Apesar de que a tendência geral da variação da forma dos quelípodos de ambas as espécies é quase semelhante, a variação morfológica dos quelípodos $C$. johni ("extended mate-guarding") assemelha-se à relatada para $M$. rugosa mais do que assemelha-se P. monodon ("short mate-guarding"). Nossos resultados são consistentes com os resultados anteriores e sugerem que a variação na forma do quelípodo (de uma forma reta e fina para um formato arqueado) é ou foi sujeita à seleção sexual através da competição entre machos.

Descritores: Cervimunida johni, Pleuroncodes monodon, Morfometria geométrica, Estratégia reprodutiva. 


\section{INTRODUCTION}

The yellow squat lobster Cervimunida johni PORTER 1903 and the red squat lobster Pleuroncodes monodon H. MILNE EDWARDS 1837 inhabit the oxygen minimum zone on the continental margin off Chile. In spite of being target of a trawl fishery operating on the continental margin along the Chilean coast, the general biology of these two species is only poorly known (THIEL and LOVRICH, 2011). Few studies have focused on the reproductive biology of these species, especially in $P$. monodon: PALMA (1994) and RIVERA and SANTANDER (2005) have reported the presence of larval stages in the plankton, and PALMA and ARANA (1997) have studied the developmental stages of embryos in the egg mass. ESPINOZA-FUENZALIDA et al. (2012) reported that females of both species mate during the intermolt period and become receptive shortly after having released larvae from a previous brood, when they form pairs with males. The interbrood interval (from larval release until having a subsequent brood) differs between the two species, being considerable longer in females of $P$. monodon than in $C$. johni. In addition, both species also differ in terms of sexual size dimorphism, duration of copulatory mate-guarding and mate-finding ability (ESPINOZA-FUENZALIDA et al., 2012). Based on differences in the reproductive biology, the latter authors suggested that males of C. johni aggressively compete for access to females while males of $P$. monodon might use the "pure searching" strategy to find receptive females. Accordingly, it is expected that the reported differences in the reproductive strategy of $C$. johni and P. monodon should be reflected in their morphologies, especially in those structures directly or indirectly related to reproduction.

Morphological variations related to different reproductive strategies have been extensively reported in decapods, particularly in cheliped morphology (see MARIAPPAN et al., 2000). In decapod crustaceans, the first pereopod generally bears a chela (claw) formed by a modification of the dactylus and propodus and is commonly known as cheliped. This appendage is typically used in feeding, defense against predators and agonistic behavior, and has therefore been considered a multifunctional organ (BROWN et al., 1979; LEE, 1995). Due to their simple basic structure, their various functions and their well-known mechanics, chelipeds are good models to study the evolution of morphology (CLAVERIE and SMITH, 2007). In squat lobsters, the patterns of cheliped form (shape and size) variation have been related to sexual dimorphism and mating interactions. Specifically, CLAVERIE and SMITH, (2010), reported an unusual cheliped size and shape dimorphism, in addition to a considerable variation in cheliped form, from straight and slender to an arched morphology in Munida rugosa (Fabricius), a common galatheid from the northeast Atlantic. These morphological differences, which are to some extent similar to differences between the well-known cutter and crusher cheliped shape in other decapods (YAMADA and BOULDING, 1998), has been related to sexual selection through male-male competition for mates. The arched morphology, which is stronger and is adapted to inflict puncture wounds during intense agonistic interactions, appeared only in larger individuals (usually above the minimal size of morphological maturity) and compared with equivalent-sized males, the arched morphology does not develop fully in females (see also CLAVERIE and SMITH, 2007).

Considering the reported difference in the reproductive strategies of $C$. johni and $P$. monodon, we hypothesized that cheliped form variation differs between the two species. Specifically we expected that cheliped form variation in the mate-guarding $C$. johni resembles that reported for $M$. rugosa, in which males also had been suggested to compete aggressively for reproductive females (CLAVERIE and SMITH, 2007, 2010). The main objective of this study was to evaluate the cheliped size and shape in order to: (1) determine whether the patterns of cheliped form described for M. rugosa were present in C. johni and in P. monodon, to (2) evaluate the relation between chelipeds shape and carapace length (allometry), and to (3) estimate the level of sexual dimorphism and whether the differences between sexes were caused by differences in cheliped size. In this purpose, we followed the general approach used by CLAVERIE and SMITH $(2007,2010)$.

\section{MATERIAL AND METHODS}

\section{SAMPle COLLECTION}

During May 2010, one hundred individuals each of C. johni (PORTER) and P. monodon (H. MILNE EDWARDS) were obtained from the commercial trawl fishery operating on the continental margin off the coast of Coquimbo, Chile (29 $\left.59^{\prime} \mathrm{S} ; 71^{\circ} 23^{\prime} \mathrm{W}\right)$. We paid special attention that the selected individuals had the carapace and both chelipeds intact, in addition to having no injuries or marks of any previous molting problem. Specimens were sorted by sex based on the shape of the pleopods (BABA et al., 2011) and body size was indexed by means of the 
carapace length $(\mathrm{CL}$, linear measurement from the base of the rostral spine to the posterior margin of the carapace at the midline), measured with a digital calliper to $0.01 \mathrm{~mm}$ accuracy (Table 1).

Table 1. Information of sample composition. n: sample size; $\mathrm{CL}$ : carapace length range (in $\mathrm{mm}$ ) and sex-specific percentage of correct assignation after leave-one-out cross-validation. The percentage of size-corrected variables is given in parentheses (further explanations in the results section).

\begin{tabular}{lcccc}
\hline & & $\mathbf{n}$ & $\mathbf{C L}(\mathbf{m m})$ & \% of correct assignation \\
\hline C. johni & female & 43 & $25.3-38.3$ & $97.6(51.1)$ \\
& male & 57 & $29.8-49.2$ & $94.7(49.1)$ \\
P. monodon & female & 47 & $29.4-36.9$ & 87.2 \\
& male & 53 & $32.2-39.9$ & 86.7 \\
\hline
\end{tabular}

\section{DATA ACQUISITION AND IMAGE ANALYSIS}

The lateral surface of each cheliped (right and left) was photographed with a digital camera (NIKON Coolpix L20, 5 megapixels) in macro mode, setting the picture plane parallel to the cheliped lateral surface (Fig. 1). The photographic procedure (e.g. avoiding distortions and considering scaling procedure and cheliped orientation) was replicated from CLAVERIE and SMITH (2010). Briefly, each cheliped was held extended and horizontal for the photograph using a custom made jig, and a small translucent elastic band was used to hold the cheliped closed. Since the propodus and dactylus are only slightly curved laterally, analysis of the cheliped form in two dimensions was considered adequate and chelipeds were analyzed using the 2D landmark-based geometrics method (ROHLF and MARCUS, 1993). Images were compiled, scaled and digitized in the TpsUtil and TpsDig programs (ROHLF, $2010 \mathrm{a}, \mathrm{b})$. In order to achieve a good representation of the cheliped form, 6 landmarks (BOOKSTEIN, 1997) were digitized (Fig. 1). Landmark configuration was homologous to those used previously by ROSENBERG (2002) for fiddler crabs (Uca spp.) and by CLAVERIE and SMITH (2007, 2010) for Munida rugosa, and was chosen considering their homology and their ability to capture the general shape of chelipeds (Fig. 1). Landmark configurations were optimally aligned using a Generalized Procrustes Analysis (GPA; ROHLF and SLICE, 1990) to remove the effects of translation, rotation and scale. After GPA, shape variables (Procrustes coordinates) and centroid size (CS) were used in the morphometric and statistical analyses. CS was computed as the square root of the sum of squares of the distances from all landmarks to their centroid and was used as a proxy of cheliped size. In order to control and exclude any specimen strongly deviating from the average, both the total sample and within each sex-specific group were inspected for outliers according to the standard procedure reported in MorphoJ program (KLINGENBERG, 2011). Due to the fact that the preliminary screening for outliers (results not shown) showed a good correspondence between the observed data and shape distances expected under a multivariate normal distribution model, we did not exclude any specimens from the analysis.

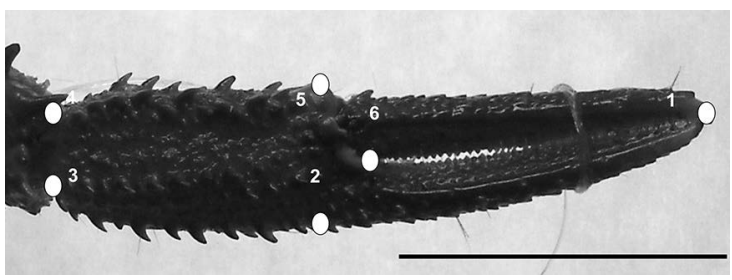

Figure 1. Right cheliped with the landmark configuration: (1) the tip of the pollex, (2) the junction between the pollex and the manus on the inferior margin of the propodus, $(3,4)$ the lower and upper attachment points of the carpus with the propodus, and $(5,6)$ the upper and lower points marking the junction of the dactylus with the propodus. The scale bar $=10 \mathrm{~mm}$. Landmark configuration was adapted from Rosemberg (2002) and from Claverie and Smith (2010).

\section{DATA ANALYSIS}

For the purpose of this study, the geometric morphometric and the statistical analyses were performed separately for both species with the MorphoJ program v1.05a (KLINGENBERG, 2011). In order to quantify the relative magnitudes of size and shape variation at different levels (sexes, individuals and appendage sides), a preliminary Procrustes ANOVA (KLINGENBERG and MCINTYRE, 1998) was carried out. Briefly, differences in cheliped size and shape were tested by partitioning the total variance into its components, which were statistically compared in a hierarchical design (i.e. to assess if sex differences were larger than differences between individuals within each sex, and whether these were larger than differences between appendage sides of the same individual). Results revealed that appendage side (shape heterochely) only differ in $C$. johni $(\mathrm{F}=14.68$ and $\mathrm{F}=11.23$ for females and males, respectively; $\mathrm{d} . \mathrm{f}=8$ for both). Nevertheless, the relative amount of shape variation (Mean Squares) due to appendage side was negligible in relation to the strong differences in cheliped shape between sexes and among individuals. Results for cheliped size largely mirrored those for shape, but did not differ among appendage side in any case. Based on these results, the 
appendage sides were pooled within each individual and average cheliped data (average size and shape of the left and right cheliped) were used throughout all subsequent analyses.

\section{FORM VARIATION}

The patterns of form variation were assessed by performing a Principal Component Analysis (PCA) on Procrustes coordinates. PCA allows visualizing and exploring the trend in form variation by means of a graphical representation of the form across a morphospace of reduced dimensions defined by the scores of the first principal components (ZELDITCH et al., 2012).

\section{Cheliped allometry AND SEXUAl Dimorphism}

The relationship between cheliped shape and carapace length was evaluated by means of a multivariate regression of shape variables on CL. The statistical significance was tested with permutation tests against the null hypothesis of independence (GOOD, 2000), and the strength of the association was assessed by means of the percentage of shape variance explained by CL (KLINGENBERG, 2011). The regression routine computes a regression score for each cheliped and the scatterplot of the regression scores against the $\mathrm{CL}$ provides a graphical means to examine the cheliped shape change as unit of carapace length change (DRAKE and KLINGENBERG, 2008). The allometric trajectories were compared by means of a permutational multivariate analysis of covariance (PERMANCOVA, ANDERSON et al., 2004) with CL as covariate. In order to exclude any bias from the analysis (for examples see ANDERSON, 2001), only specimens within the same carapace length range (from 29.7 to 38.3 $\mathrm{mm}$ for $C$. johni and from 31.5 to $36 \mathrm{~mm}$ for P. monodon) were included in PERMANCOVA. Given the presence of groups, prior to PERMANCOVA we assessed the differences in slopes of allometric trajectories. In both species the CL by sex interaction term was analyzed throughout the comparison of multivariate regression slopes between groups with TpsRegr (ROHLF, 2010c). Briefly, the test for slopes compares the amount of variance explained by two models: one is simultaneously fitting group-specific multivariate linear regressions with each population having its own slope, while the second one is also fitting group-specific lines but it does so by forcing them to be parallel (see VISCOSI and CARDINI,
2011 for details). As the differences among slopes were found to be not significant $(p>0.05)$, all subsequent analysis were performed by using the same alometric trajectory for groups. Sexual dimorphism in cheliped size was assessed by permutational tests, whereas form (shape and size) differences were tested by applying a Discriminant Analysis (DA). The reliability of the discrimination of shape variables was calculated by leaveone-out cross-validation (e.g. LACHENBRUCH, 1967). DA was repeated on non-allometric shape variables (sizecorrected) to evaluate the sexual dimorphism without the allometric effect. Size-corrected variables were obtained as reported in LEZCANO et al. (2012).

\section{RESULTS}

For C. johni, the first 2 principal components (PCs) of the PCA accounted for $75.4 \%$ of the total cheliped form variation $(61 \%$ for $\mathrm{PC} 1$ and $14.4 \%$ for $\mathrm{PC} 2$; Fig. 2A). For P. monodon, PC1 accounted for $50.5 \%$ and PC2 for $20.6 \%$ (together they accounted for $71.1 \%$ of the total form variation; Fig. 2B). In both species, the examination of the wireframe representations of extreme forms on each axis indicates that PC1 mainly represents an inverse relationship between pollex (distal extension of the propodus) length and both manus (proximal part of the propodus) length and propodus height. Data points for females were associated with narrower chelipeds, and males were related with high propodus, long manus and short pollex. Males of $C$. johni showed the widest variation in cheliped form and the fully arched morphology (i.e. with a relatively shorter pollex and a longer manus; Fig. $2 \mathrm{~A}, \mathrm{~B})$. The second axis represents the degree of bending of the cheliped in the vertical plane, with an inflection point at the base of the pollex.

The multivariate regression of cheliped shape on $\mathrm{CL}$ was significant $(p<0.05$; permutation test with 10,000 random permutations) in both species (Fig. 2C, D), but $\mathrm{CL}$ accounted for a slightly larger amount of the total shape variation in C. johni than in P. monodon (13.4\% and $9.2 \%$, respectively). The cheliped shape change relative to CL was similar in both species: chelipeds change, on average from a long and narrow pollex with short manus to a relatively shorter and wider pollex with longer manus during growth (i.e. from small to large CL). The degree of cheliped arching was greater in males than in similar-sized females, and only C. johni males showed the fully arched 
A
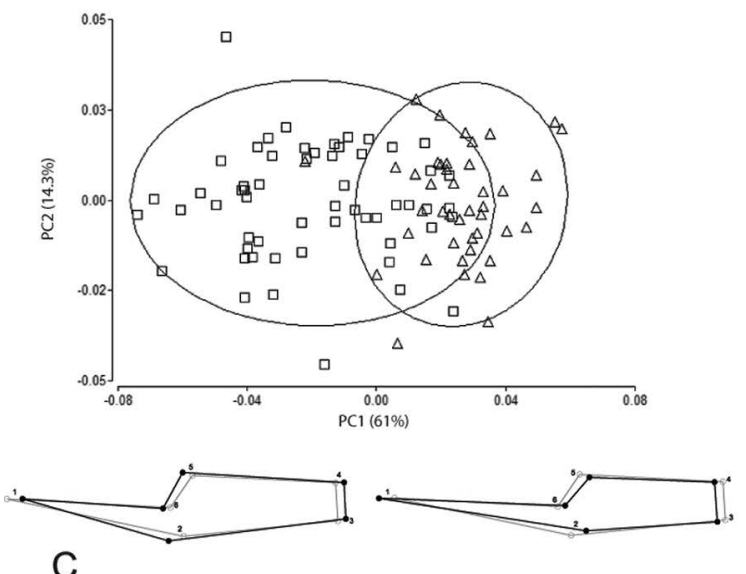

C
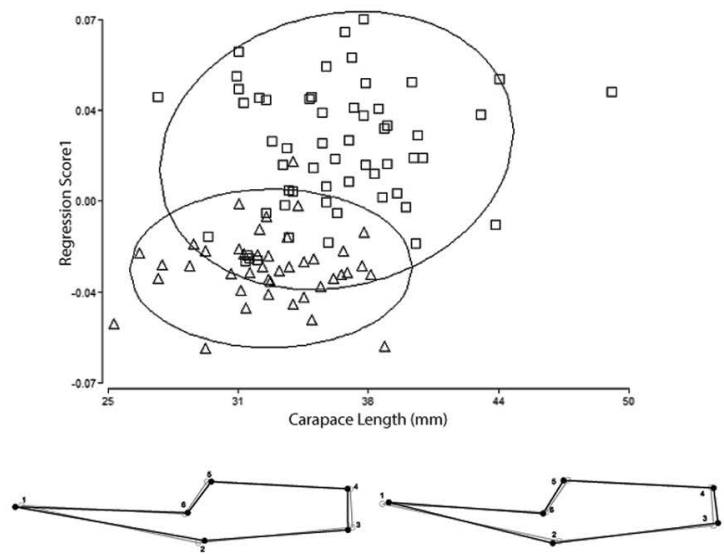

B
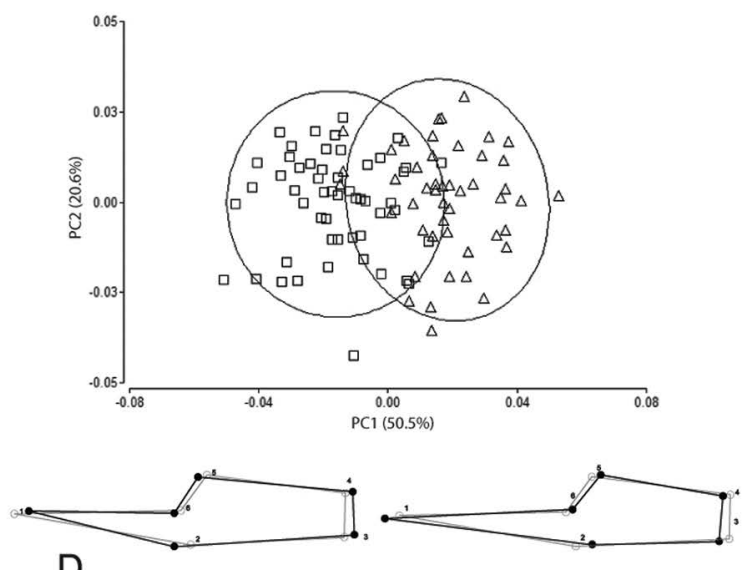

D

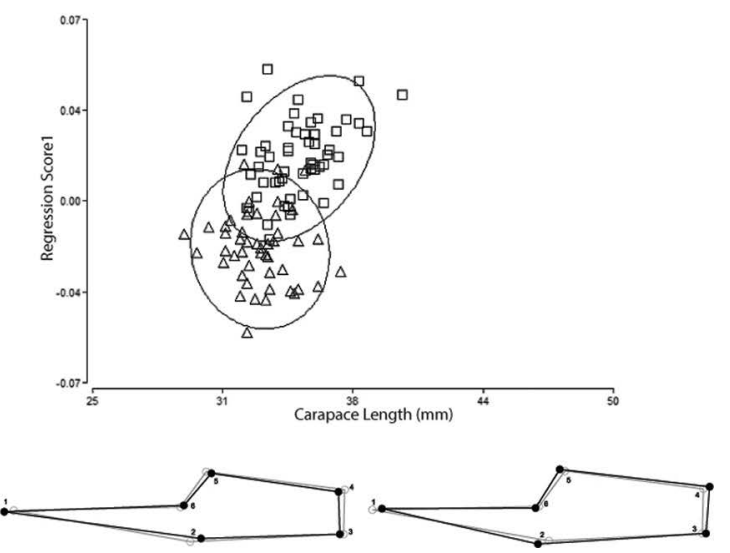

Figure 2. Plot of the principal components (PCs; upper) and of multivariate regression of cheliped shape onto carapace length (lower) of Cervimunida johni (A-C) and Pleuroncodes monodom (B-D). A-B: figures represent the displacement vectors (wireframe) from the overall mean shape (grey) to the positive and negative extreme shape (black) for PC1. Shape changes have been exaggerated (scale factor 0.1) for better visualization and percentages of explained variance for each axis are in parentheses. C-D: shape (Regression Score 1) as a function of carapace length, illustrating cheliped allometric growth of sexes. Wireframes represents the opposite extremes of allometric variation: the average cheliped shape and the change from the grey circles to the black dots indicates the predicted landmark shift corresponding to an increase and decrease of centroid size by 15 scale factor. Symbols: triangle for females; square for males.

morphology (Fig. 2C). Results from the PERMANCOVA also showed that cheliped shape was affected by CL and mirrored the influence of these estimates on cheliped shape reported by the multivariate regression. Differences between sexes (intercept) were significant in both species (Fig. 2C, D) and the allometric trajectories were largely aligned with vectors of mean shape differences, with males of both species extending the cheliped trajectories to larger body sizes (Fig 2C, D).

Permutational tests confirmed that cheliped size (CS) differed significantly between sexes $(p<0.001 ; 10.000$ random permutations) in both species. The results of the Discriminant Analysis showed that mean cheliped form differed between sexes (Fig. 3) and the accuracy of group discrimination was high in all sex-specific groups (Table
1). Because CS was only significantly related to cheliped shape in $C$. johni, size-corrected variables were calculated for sexes only in this species. The difference between size-corrected variables was not significant $(p>0.05)$ and the accuracy in the discrimination of groups strongly decreased (Table 1).

\section{DISCUSSION}

Here we present the first study comparing cheliped form variation of two species of squat lobsters of commercial importance which inhabit the continental margin of Chile: Cervimunida johni and Pleuroncodes monodon. Using the general approach of CLAVERIE and SMITH (2010), we confirmed that cheliped size and 
A
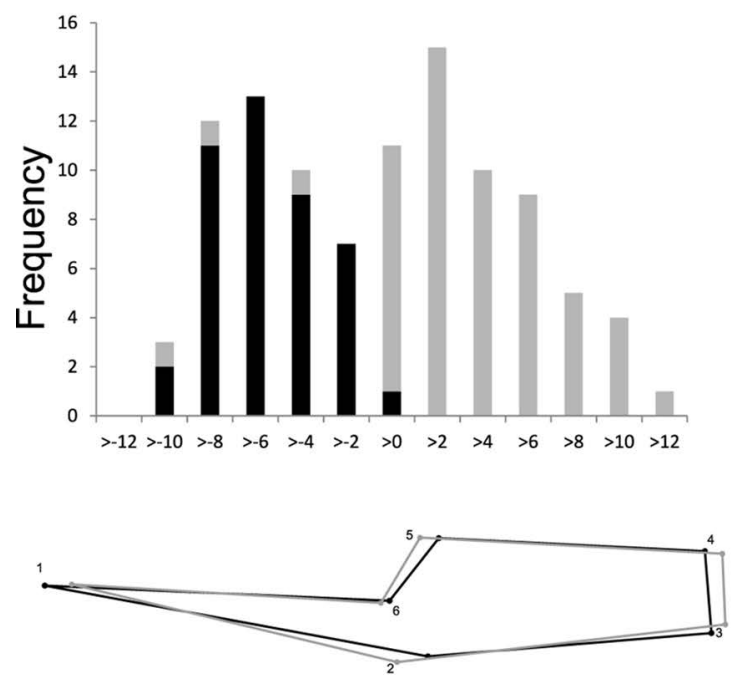

B
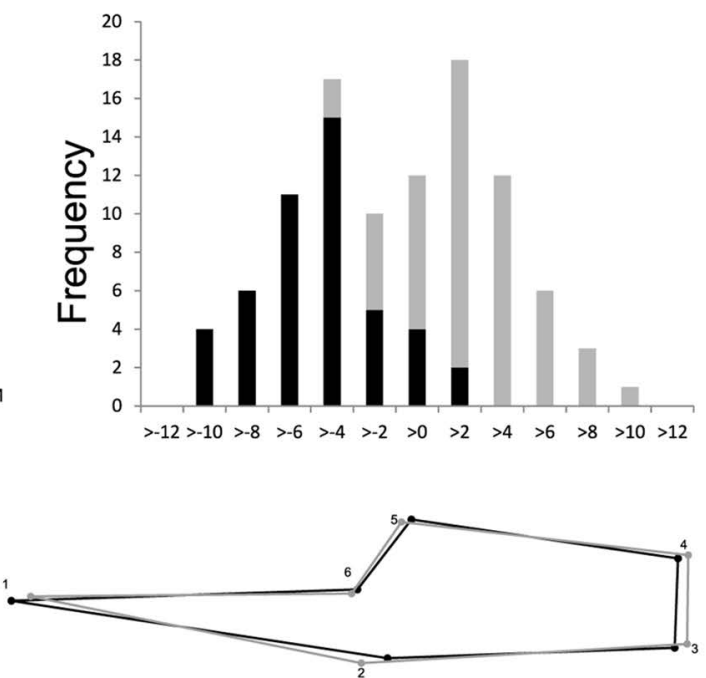

Figure 3. Discriminant analysis for sex differences of Cervimunida johni (left) and Pleuroncodes monodon (right). Frequencies (y axis) of the discriminant scores ( $\mathrm{x}$ axis) by a jackknife (leave-one-out) cross-validation are shown using histogram bars. Mean shapes of female and male chelipeds are visualized using wireframe graph magnified 2 times. Grey and black wireframes are for females and males, respectively.

shape of these species is related to known aspects of their reproductive biology, particularly the mating behavior.

In addition to duration of mate-guarding and resource finding and monopolization, $C$. johni and P. monodon also differ in terms of their mobility and intraspecific aggression (ESPINOZA-FUENZALIDA et al., 2012). $P$. monodon is much more active and aggressive than $C$. johni. Even more, pelagic phases have been reported from the genus Pleuroncodes, underlining their high mobility (BOYD, 1967; ROBINSON and GOMEZ-AGUIRRE 2004). Differences in aggregation patterns were also reported (AHUMADA et al., 2013) and the estimated average density of $P$. monodon was usually larger than that of $C$. johni. As the objective of this study was to examine the relationship between mate-guarding and cheliped form variation, the influence of all aforementioned factors (mobility, aggregation patterns, etc.) on cheliped form have not been taken into account, which should be done in future studies.

Cheliped form variation was similar in P. monodon and C. johni, but the degree of arching was greater in males, especially in those of $C$. johni. Similar wide variation in cheliped morphology (from straight to arched) was previously revealed in other squat lobsters, particularly in Munida spp. (CLAVERIE and SMITH 2007; 2010 and references therein). These authors suggested that this morphology was present in a common ancestor or the extant species had convergent morphological evolution due to similar selection pressures. The arched morphology is considered a sexually selected trait, adapted to inflict puncture wounds on opponents during agonistic interactions. Males with arched chelipeds are thought to be more successful in agonistic interactions and/or in obtaining and handling mates than those with straight chelipeds. Our results support the hypothesis reported by CLAVERIE and SMITH (2007), since males of $C$ johni, a species with extended mate-guarding, presents fully arched chelipeds that serve as a weapon during antagonistic encounters, while $P$. monodon with brief mate-guarding did not develop this morphology.

Asymmetry in chelipeds (cheliped laterality or handedness) of lobsters and other decapod crustaceans has been extensively reported (e.g., GOVIND, 1989; LEE, 1995; SCHENK and WAINWRIGHT, 2001; DENNENMOSER and CHRISTY, 2013). Asymmetry involves both, functional and structural differences among appendage sides and is mainly due to differences in feeding and locomotion, but also to sexual behavior (for examples see MARIAPPAN et al., 2000). In otherwise symmetric specimens, regeneration after autotomy could also cause asymmetry (CLAVERIE and SMITH, 2010). In $M$. rugosa, CLAVERIE and SMITH (2010) have found significant differences among cheliped sides and suggest that chelipeds play different roles in fighting and/ or feeding. In our study, we found that while $P$. monodon showed neither cheliped shape nor size differences among 
appendage sides, C. johni showed small (negligible compared with other levels of cheliped variation) but significant cheliped shape asymmetry. Until further studies in C. johni assess the strength of asymmetry, and whether it is the result of differences in function/structure or autotomy, we assume that chelipeds in both C. johni and $P$. monodon are symmetric among sides and play similar functions.

Even when the general patterns of within-sex cheliped shape variation was almost similar in both species (wide cheliped variation in males of C. johni; see above), sexual dimorphism was clearly different, particularly in the strength of differences and in the relation with both, carapace length and cheliped size. Sexual dimorphism in carapace length and in cheliped size was previously reported for both species (see CLAVERIE and SMITH, 2010 and references therein) and confirmed in our study, where males are larger than females and develop larger chelipeds. For both species, the proportion of specimens with arched chelipeds increased, on average, with increasing cheliped and body size. However, a considerable proportion of large males maintained straight chelipeds, especially in $C$. johni. Cheliped size was related to cheliped shape only in C. johni. Moreover, sexual dimorphism in cheliped shape is mainly due to differences in cheliped size; after correcting for size effects, no sexual dimorphism was found, similar as in some brachyuran crabs (LEE, 1995). The allometric patterns of cheliped shape variation (cheliped shape vs. carapace length) follow the same developmental pathways in both sexes, with males extending the cheliped trajectories to larger body sizes. Nonetheless, the allometric trajectories were largely aligned with vectors of mean shape differences, suggesting that chelipeds differ among sexes even in small specimens.

Sexual dimorphism in chela features (arched morphology) appears to be more pronounced in the species with long mate-guarding $(C$. johni) than in the species with short mate-guarding ( $P$. monodon). These findings are in accordance with the conclusions by LEE (1995) who suggested that species with prolonged mateguarding have stronger sexual dimorphism in chela size than species without or with short mate-guarding. This may result from strong sexual selection on chelae size and shape in males that guard females for long time periods. During prolonged mate-guarding males may frequently have to fend off other males, generating advantages for males with large and powerful chelae. In the crab Carcinus maenas, where males guard premolt females for extensive time periods (BERRILL and ARSENAULT, 1982), males with larger chelae were significantly more successful in winning fights than males with small chelae (SNEDDON et al., 1997). In crayfish Orconectes rusticus males with larger claws were more successful in winning intrasexual encounters, and their matings with females lasted significantly longer than those of small claw males (SNEDDEN 1990). Thus, in species with prolonged mate-guarding sexual selection seems to drive intersexual differences in chela morphology.

In summary, the main results of our study is that cheliped form variation reflect the reported differences in both species: C. johni which is an extended mateguarding species, presents a wide cheliped form variation (specifically in males), strong sexual dimorphism (highly related to cheliped size) and allometry with carapace length that match the morphology reported for M. rugosa more than P. monodon, a species with short mate-guarding.

\section{ACKNOWLEDGEMENTS}

We would like to thank Ma. Laura Rojas Quiroga. Early versions of the manuscript were greatly improved by her comments. An anonymous reviewer provided interesting insights that dramatically enhanced this manuscript. The authors also thank the SI-COLACMAR of BJO.

\section{REFERENCES}

AHUMADA, M., QUEIROLO, D., ACUÑA, E.; GAETE, E. Caracterización de agregaciones de langostino colorado (Pleuroncodes monodon) y langostino amarillo (Cervimunida johni) mediante un sistema de filmación remolcado. Lat. Am. J. Aquat. Res., v. 41, n. 1, p. 199-208, 2013.

ANDERSON, M. J. A new method for non-parametric multivariate analysis of variance. Austral. Ecology, v. 26, n. 1, p. 32-46, 2001

ANDERSON, M. J.; FORD, R. B.; HONEYWILL, C.; FEARY, D. Quantitative measures of sedimentation in an estuarine system and its relationship with intertidal soft-sediment infauna. Mar. Ecol. Prog. Ser., v. 272, p. 33-48, 2004.

BABA, K., AHYONG, S. T.; MACPHERSON, E. Morphology of marine squat lobsters. Biol. Squat Lobsters, v. 20, n. 1, 2011.

BERRILL, M.; ARSENAULT, M. Mating behavior of the green shore crab Carcinus maenas. Bull. Mar. Sci., v. 32, n. 2, p. 632-638, 1982.

BOOKSTEIN, F. L. Morphometric tools for landmark data: geometry and biology. Cambridge: Cambridge University Press, 1997.

BOYD, C. M. The benthic and pelagic habitats of the red crab, Pleuroncodes planipes. Pac. Sci., v.21, n. 3, p. 394-403, 1967. 
BROWN, S. C.; CASSUTO, S. R.; LOOS, R. W. Biomechanics of chelipeds in some decapod crustaceans. J Zool., v. 188, n. 2, p. 143-159, 1979.

CLAVERIE, T.; SMITH, I. P. Functional significance of an unusual chela dimorphism in a marine decapod: specialization as a weapon? Proc. Biol. Sci., v. 7, n. 270, p. 3033-3038, 2007.

CLAVERIE, T.; SMITH, I. Allometry and sexual dimorphism in the chela shape in the squat lobster Munida rugosa. Aquat. Biol., v. 8. p. 179-187, 2010.

DENNENMOSER, S., CHRISTY, J. H. The design of a beautiful weapon: compensation for opposing sexual selection on a trait with two functions. Evolution, v. 67, n. 4. p. 1181-1188, 2013.

DRAKE, A. G.; KLINGENBERG, C. P. The pace of morphological change: historical transformation of skull shape in St Bernard dogs. Proc. R. Soc. Lond., v. 275, n. 630, p. 71-76, 2008.

ESPINOZA-FUENZALIDA, N. L.; ACUÑA, E., HINOJOSA, I. A.; THIEL, M. Reproductive biology of two species of squat lobsters-female receptivity and interbrood intervals. J. Crustac. Biol., v. 32, n. 4. p. 565-574, 2012.

GOOD, P. Permutation tests. New York: Springer, 2000.

GOVIND, C. K. Asymmetry in lobster claws. Am. Sci., v. 77, p. 468-474, 1989.

KLINGENBERG, C. P.; MCINTYRE, G. S. Geometric morphometrics of developmental instability: analyzing patterns of fluctuating asymmetry with Procrustes methods. Evolution, v. 52, n. 5, p. $1363-1375,1998$.

KLINGENBERG, C. P. MorphoJ: an integrated software package for geometric morphometrics. Mol. Ecol. Res., v. 11, n. 2, p. 353-357, 2011.

LACHENBRUCH, P. A. An almost unbiased method for the probability of misclassification in discriminant analysis. Biometrics, v. 23, p. 639-645, 1967.

LEE, S. Y. Cheliped size and structure: the evolution of a multi-functional decapod organ. J. Exp. Mar. Biol. Ecol., v. 193, n. 1, p. 161-176, 1995.

LEZCANO, A. H.; GONZÁLEZ-JOSÉ, R.; SPIVAK, E. D.; DELLATORRE, F. G. Geographic differences in the carapace shape of the crab Cyrtograpsus affinis (Decapoda: Varunidae) and its (their?) taxonomic implications. Sci. Mar., v. 76, n. 2, p. 329-337, 2011.

MARIAPPAN, P., BALASUNDARAM, C.; SCHMITZ, B. Decapod crustacean chelipeds: an overview. J. Biosci., v. 25, n. 3, p. 301-313, 2000.

PALMA S. Distribución y abundancia de larvas de langostino colorado Pleuroncodes monodon frente a la costa de Concepción, Chile. Invest. Mar., v. 22, p. 13-29, 1994.

PALMA, G.; ARANA, P. Aspectos reproductivos del langostino colorado (Pleuroncodes monodon H. Milne Edwards, 1837), frente a la costa de Concepción, Chile. Invest. Mar., v. 25, p. 203-221, 1997.
RIVERA, J.; SANTANDER, E. Variabilidad estacional de la distribución y abundancia de larvas de langostino colorado en la zona norte de Chile (Decapoda, Anomura, Galatheidae). Invest. Mar., v. 33, n. 1, p. 3-23, 2005.

ROBINSON, C. J.; GOMEZ-AGUIRRE, S. Tidal stream use by the red crab Pleuroncodes planipes in Bahía Magdalena, Mexico. J. Exp. Mar. Biol. Ecol., v. 308, n. 2, p. 237-252, 2004.

ROHLF, F. J.; SLICE, D. Extensions of the Procrustes method for the optimal superimposition of landmarks. Syst. Biol., v. 39, n. 1 , p. 40-59, 1990.

ROHLF, F. J.; MARCUS, L. F. A revolution in morphometrics. Trends. Ecol. Evol., v. 8, n. 4, p. 129-132, 1993.

ROHLF, F. J. tpsUtil program, Version 1.46. New York: Department of Ecology \& Evolution, State University of New York, 2010a.

ROHLF, F. J. tpsDig program, Version 2. 16. Stony Brook: Ecology and Evolution, SUNY, 2010b.

ROHLF, F. J. tpsRegr, Version1. 37. New York: Department of Ecology \& Evolution, State University of New York, 2010c.

ROSENBERG, M. S. Fiddler crab claw shape variation: a geometric morphometric analysis across the genus Uca (Crustacea: Brachyura: Ocypodidae). Biol. J. Linn. Soc., v. 75, n. 2, p. 147-162, 2002.

SCHENK, S. C.; WAINWRIGHT, P. C. Dimorphism and the functional basis of claw strength in six brachyuran crabs. J. Zool., v. 255, n. 1, p. 105-119, 2001.

SNEDDEN, W. A. Determinants of male mating success in the temperate crayfish Orconectes rusticus: chela size and sperm competition. Behaviour, v. 115, n. 1/2, p. 100-113, 1990.

SNEDDON, L. U.; HUNTINGFORD, F. A.; TAYLOR, A. C. Weapon size versus body size as a predictor of winning in fights between shore crabs, Carcinus maenas (L.). Behav. Ecol. Sociobiol., v. 41, n. 4, p. 237-242, 1997.

THIEL, M.; LOVRICH, G. A. Agonistic behaviour and reproductive biology of squat lobsters. In: POORE, G. C. B.; AHYONG, S. T.; TAYLOR, J. (Eds.). The Biology of Squat Lobsters. Melbourne/Boca Raton: CSIRO Publishing/CRC Press, 2011. p. 223-247.

VISCOSI, V.; CARDINI, A. Leaf morphology, taxonomy and geometric morphometrics: a simplified protocol for beginners. PLoS One, v. 6, n.10, p. e25630, 2011.

YAMADA, S. B.; BOULDING, E. G. Claw morphology, prey size selection and foraging efficiency in generalist and specialist shell-breaking crabs. J. Exp. Mar. Biol. Ecol., v. 220, n. 2, p. 191-211, 1998.

ZELDITCH, M. L.; SWIDERSKI, D. L.; SHEETS, H. D.; FINK W. L. Geometric morphometrics for biologists: a primer. New York, London: Elsevier Academic Press, 2012. 